\title{
China and the Humanities
}

At the Crossroads of the Human and the Humane

\section{Edited by}

W. KANG TCHOU
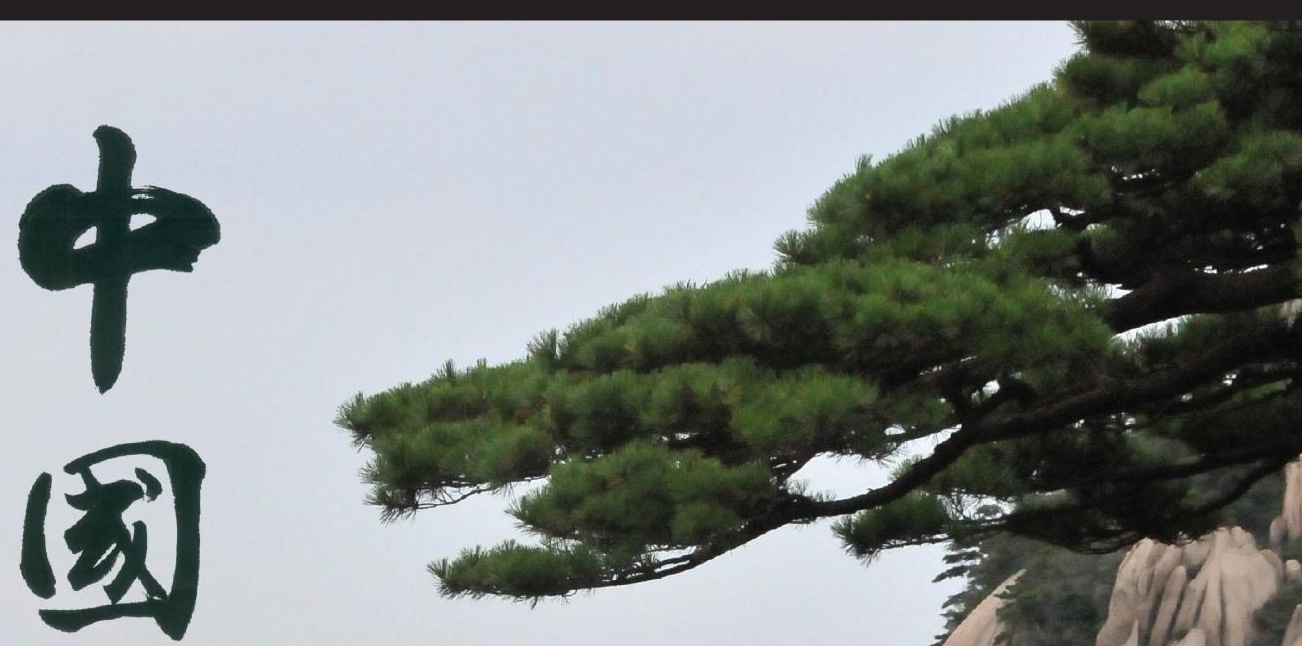

息 $\frac{\sqrt{2}}{r}$
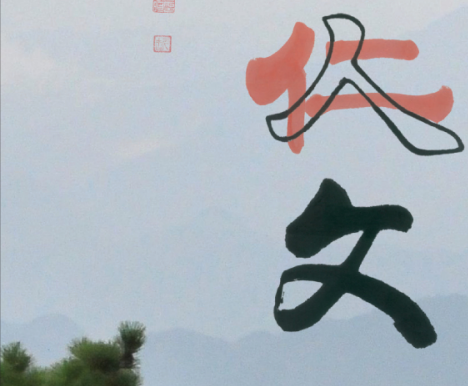

\section{$\left(\begin{array}{lllllll} & C & O & M & M & O & N \\ G & R & 0 & U & N & D\end{array}\right.$}

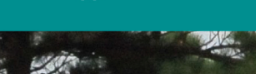






\section{CHINA AND THE HUMANITIES}

AT THE CROSSROADS OF THE HUMAN AND THE HUMANE 中国与人文和仁文 



\section{CHINA AND THE HUMANITIES}

AT THE CROSSROADS OF THE HUMAN AND THE HUMANE 中国与人文和仁文

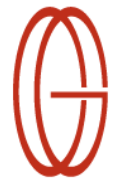

Common Ground 
First published in Champaign, Illinois in 2013

by Common Ground Publishing LLC

at the series imprint The Humanities

Selections and editorial matter copyright (C) Kang Tchou 2013;

Individual chapters copyright $@$ C individual contributors 2013

All rights reserved. Apart from fair dealing for the purposes of study, research, criticism or review as permitted under the applicable copyright legislation, no part of this book may be reproduced by any process without written permission from the publisher.

\section{Library of Congress Cataloging-in-Publication Data}

China and the humanities : at the crossroads of the human and the humane / editor: Kang Tchou. -- Ist ed.

$$
\text { p. cm. -- (The Humanities) }
$$

Includes index.

ISBN 978-I-86335-85I-4 (pbk : alk. paper) -- ISBN 978-I-6I229-I26-O (pdf)

I. Humanities--China. 2. Arts, Chinese--2Ist century. 3. Humanity--China. I. Tchou, Kang.

$\mathrm{AZ}_{791 . \mathrm{C}_{45} 82 \mathrm{II}}$

oor.3095I--dc22 
This volume of collected essays is dedicated to all those who are not from China but have fallen in love with China. It is also for all those who are from China and have fallen in love with other cultures, be it at the age of nine, thirty, or seventy-six. 


\section{Table of Contents}

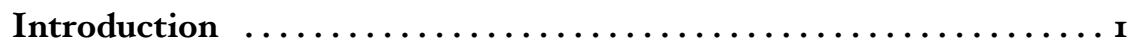

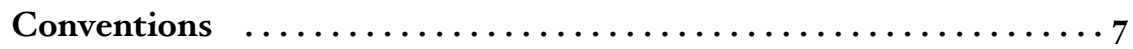

Part I : A Culture of Humaneness | 仁义文化

Chapter I: Human Rights in China, and My Experiences $\ldots \ldots \ldots$ I3 吴青 [WÚ qing]

Chapter 2: Love for Neighbours $\ldots \ldots \ldots \ldots \ldots \ldots \ldots \ldots \ldots \ldots$ using Kierkegaard to respond to Žižek Alison ASSITER

Chapter 3: "Student Engagement" $\ldots \ldots \ldots \ldots \ldots \ldots \ldots \ldots \ldots \ldots 43$ Thoughts on the Anniversary of the Tiananmen Student Uprising fudy LATTAS

Part II : The Humanities in China | 中国的人文学

Chapter 4: Shāng Dynasty Oracle Bone Agency .............6. 63 Its Contemporary Philosophical Significance Astrid VICAS

Chapter 5: From Heroes to Villains $\ldots \ldots \ldots \ldots \ldots \ldots \ldots \ldots \ldots \ldots \ldots \ldots \ldots$ Comparison between the 明朝 [míng cháo or Ming Dynasty] Novel of 水湤传 [shuǐ hǔ zhuàn] and the 清朝 [qīng cháo or Qing Dynasty] Adapted Court Play of 忠义璇图 [zhōngyì xuán tú] Sasiporn PETCHARAPIRUCH

Chapter 6: Virginia Woolf in Contemporary Chinese Media ......97 An Investigation 曹小琴 [CAOO xiăo qin]

Chapter 7: The Cinematic Transformation in Post-Socialist China II5 A Case Study of 张艺谋 [ZHĀNG yì móu]'s 满城尽带黄金甲 [măn chéng jìn dài huáng jīn jiă or Curse of the Golden Flower] 马纶鹏 [MĂ lún péng] 
Part III : Humanities' Mark on People | 以人文和仁文化人

Chapter 8: 1'Université l'Aurore [震旦大学 zhèn dàn dà xué]

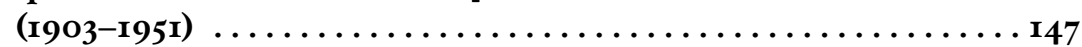

The Relevance of a Foreign University in China

Cécile LEUNG

Chapter 9: Governance on the Production of Identity .......... I6I

Consuming Western High-Culture in Contemporary 上海 [shàng hái or

Shanghai]

徐舫 [XÚfäng]

Chapter Io: Teaching an "Other" Literature in China .......... I89

Is the Speaker of Dylan Thomas's "Do Not Go Gentle Into That Good

Night" a Good Son?

Charles LOWE

Chapter II: Assimilative Apprehensions and Strategic Responses . 197 Uyghur Counter-Narratives

Robert Warren WILSON

Chapter 12: Providing Equal Opportunity and a Chance for

Development to Ethnic Minority Girls ............. 217

A Case Study of the Rural Women's Scholarship Project at The

Practical Skills Training School for Rural Women

罗兆红 [LUÓ zhào hóng]

Epilogue

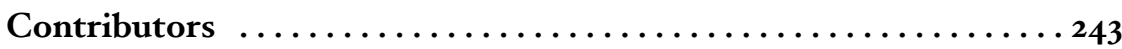

Index $\ldots \ldots \ldots \ldots \ldots \ldots \ldots \ldots \ldots \ldots \ldots \ldots \ldots \ldots . . .249$ 